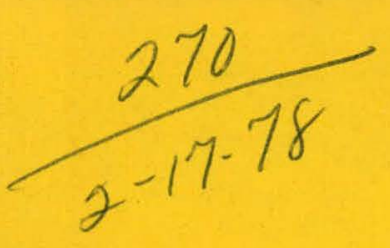

MLM-2499

\title{
Development of Ultrafiltration and Inorganic Adsorbents for Reducing \\ Volumes of Low-Level and \\ Intermediate-Level Liquid Waste: \\ July-September 1977
}

John W. Koenst, William R. Herald

and Raymond C. Roberts

February 9, 1978

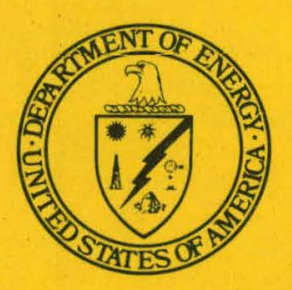

\&

Monsanto

\section{MOUND FACILITY}

Miamisburg, Ohio

operated by

MONSANTO RESEARCH CORPORATION a subsidiary of Monsanto Company

for the

U. S. DEPARTMENT OF ENERGY

Contract No. EY-76-C-04-0053 


\section{DISCLAIMER}

This report was prepared as an account of work sponsored by an agency of the United States Government. Neither the United States Government nor any agency Thereof, nor any of their employees, makes any warranty, express or implied, or assumes any legal liability or responsibility for the accuracy, completeness, or usefulness of any information, apparatus, product, or process disclosed, or represents that its use would not infringe privately owned rights. Reference herein to any specific commercial product, process, or service by trade name, trademark, manufacturer, or otherwise does not necessarily constitute or imply its endorsement, recommendation, or favoring by the United States Government or any agency thereof. The views and opinions of authors expressed herein do not necessarily state or reflect those of the United States Government or any agency thereof. 


\section{DISCLAIMER}

Portions of this document may be illegible in electronic image products. Images are produced from the best available original document. 
This report was prepared as an account of work sponsored by the United States Government. Neither the United States nor the United States Department of Energy, nor any of their employees, nor any of their contractors, subcontractors, or their employees, makes any warranty, express or implied, or assumes any legal liability or responsibility for the accuracy, completeness or usefulness of any in. formation, apparatus, product or process disclosed, or represents that its use would not infringe privately owned rights.

\section{PRINTED IN THE UNITED STATES OF AMERICA}

Available from

National Technical Information Service

U. S. Department of Commerce

5285 Port Royal Road

Springfield, Virginia 22161

Price: Printed Copy $\$ 4.00$; Microfiche $\$ 3.00$ 


\section{Development of Ultrafiltration and Inorganic Adsorbents for Reducing Volumes of Low-Level and Intermediate-Level Liquid Waste: July-September 1977}

John W. Koenst, William R. Herald and Raymond C. Roberts

Issued: February 9, 1978

\section{MOUND FACILITY}

Miemisburg. Onio 45342

operoted by

\section{MONSANTO RESEARCH CORPORATION}

a subsidiery of Monsento Compeny

for the

U. S. DEPARTMENT OF ENERGY

Contract No. EY-76-C-04-0053

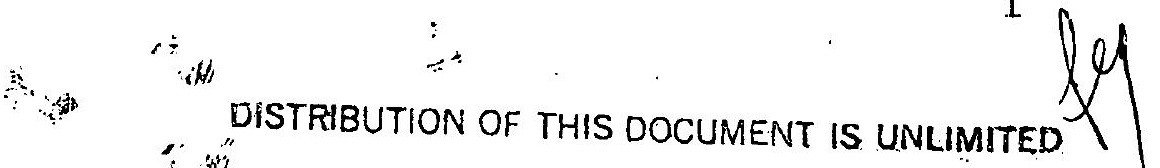




\section{Abstract}

The ultrafiltration (UF) pilot system is being evaluated at Mound Facility. The effect of pressure drop, temperature, and $\mathrm{pH}$ of the feed on system performance has been studied. The system has been run through a number of cleaning cycles including tap water flush, enzyme soak, detergent wash, and citric acid/oxalic acid wash. A continuous run was started on waste from the Waste Processing Facility; at the time of this report, approximately 11,500 gal had been processed. Studies to determine the effect of $(\alpha, \beta, \dot{\gamma})$ radiation on membrane characteristics were initiated this quarter and will be completed next quarter.

The small laboratory column tests were completed. Isotherms were run on several inorganic adsorbents, including titanium phosphate and sodium titanate. Tests were continued on the Engineering Test Ion Exchange System. Waste solution from the waste Processing Facility spiked with plutonium-238 and ultrafiltration product spiked with uranium-233 were used as feeds.

\section{Ultrafiltration}

During the month of July, a series of experiments were started on the pilot ultrafiltration system in order to determine the effect of changing the operating pressure drop $(\Delta P)$ across the system on membrane flux and rejection of activity. The system was operated at an inlet pressure (IP) of $50 \mathrm{psi}$. The outlet pressure (OP) was varied from 15 to 35 psi, thereby producing $\triangle P^{\prime}$ 's (IP-OP) from 15 to 35 psi. The results of these tests showed that flux was greater at lower $\Delta P^{\prime} s$ (Table 1).

$\left[\begin{array}{cc}\text { Table } 1-\text { RELATIONSHIP OF FLUX WITH } \Delta \mathrm{P} \\ \begin{array}{c}\text { Average Flux } \\ \text { Corrected to } 77^{\circ} \mathrm{F} \\ \text { (gal/min) }\end{array} & \begin{array}{c}\Delta \mathrm{P} \\ \text { (psi) }\end{array} \\ \begin{array}{c}1.32 \\ 1.20\end{array} & 15 \\ 1.09 & 20 \\ 1.03 & 25 \\ 0.99 & 30 \\ \hline\end{array}\right.$

Although the flux rate is somewhat higher at a low $\Delta P$, the recirculation rate and, therefore, the amount of turbulence within the membrane tube are also lower. This would most probably lead to faster fouling of the membrane surface. (A $\Delta \mathrm{P}$ of $15 \mathrm{psi}$ yields a recirculation rate of $18 \mathrm{gal} / \mathrm{min}$, whereas a $\triangle P$ of 35 psi gives a recirculation rate of $32 \mathrm{gal} / \mathrm{min}$.$) The \Delta \mathrm{P}$ appeared to have very little effect on the rejection of activity.

A series of runs was made at an elevated temperature $\left(\sim 110^{\circ} \mathrm{F}\right)$ in order to determine the effect of temperaturc on membrane performance. Flux rates were much higher at elevated temperatures (They ranged from 1.6 to $3.5 \mathrm{gal} / \mathrm{min})$; however, rejection of $\alpha$ activity was lower, ranging from 90 to 958 instead of the $99+8$ usually obtained at lower operating temperatures. All the elevated temperature runs were made at a $\Delta P$ of $25 \mathrm{psi}$. 
In the next series of runs, the $\mathrm{pH}$ of the feed solution was raised to $\mathrm{pH} 10$ or $\mathrm{pH} 11$ with the addition of $\mathrm{NaOH}$. Although the elevation of $\mathrm{pH}$ reduced the activity remaining in the permeate by about 508 (on the average), the metal hydroxide precipitate formed caused rapid fouling of the membranes and a very rapid flux decline. (Flux dropped from $2.8 \mathrm{gal} / \mathrm{min}$ to 1.2 gal/min in the first $3 \mathrm{hr}$ of operation, and down to $20.85 \mathrm{gal} / \mathrm{min}$ after two days of operation).

After the elevated $\mathrm{pH}$ runs were completed, it was necessary to thoroughly clean the system. Washing with detergent and enzymes did little to improve flux; therefore, the unit was cleaned with a 0.58 solution of citric acid followed by a 0.58 solution of oxalic acid. This succeeded in removing the heavy metal hydroxide fouling the membrane surface. After a final detergent wash and water rinse, flux had recovered to $25.5 \mathrm{gal} / \mathrm{min}$ (using tap water). This compares to $10 \mathrm{gal} / \mathrm{min}$ when the system was new and $7 \mathrm{gal} / \mathrm{min}$ after the first major cleaning.

During the month of August, a continuous run of the ultrafiltration pilot plant was started. The system was run continously at a $\Delta \mathrm{P}$ of $i 25 \mathrm{psi}$ using waste from the Waste Processing Facility containing about 25 to $30 \mathrm{mg} / 1$ iter of suspended solids. The system flux at the beginning of this experiment was $i 1.85 \mathrm{gal} / \mathrm{min}$ (corrected to $77^{\circ} \mathrm{F}$ ). This flux quickly declined to about 1.2 to $1.3 \mathrm{gal} / \mathrm{min}$ as the first 600 gal were processed by the system. The flux very slowly declined to $0.95 \mathrm{gal} / \mathrm{min}$ by the time 2400 gal had been run. At this point, the system was flushed with 200 gal of tap water and allowed to sit over a four-day period. When the system was started up again, the flux, using tap water, had recovered to $\sim 4.5 \mathrm{gal} / \mathrm{min}$. When continous running was resumed, the initial flux was $23.0 \mathrm{gal} / \mathrm{min}$. This flux rate rapidly declined to about $2 \mathrm{gal} / \mathrm{min}$ and then leveled off.

Periodic flushes with tap water maintained the flux near this level for a long period of time. After 5,000 gal had been run, flux was still about $1.9 \mathrm{gal} / \mathrm{min}$, and after $7,000 \mathrm{gal}$ a flux of $\sim 1.6 \mathrm{gal} / \mathrm{min}$ was still being obtained. Since that time, the flux has slowly declined. At the present time, $\sim 11,500$ gal have been processed and the flux is still in the 1.2 to $1.3 \mathrm{gal} / \mathrm{min}$ (corrected to $77^{\circ} \mathrm{F}$ ) range (see Table 2 and Figure 1 ).

One interesting fact that has come to light during the course of this continous run is that the " $M$ " membranes have performed better than the " $D$ " membranes. The difference in performance of the two types of membranes has increased as the run progressed. At the present time the " $M$ " membrane accounts for 2608 of the total permeate produced and also is 30 to 408 better in the rejection of activity.

Studies have been initiated to determine the effect of alpha bombardment on the membranes. Samples of both the " $D$ " and "M" membranes have been characterized as to flux with $\mathrm{H}_{2} \mathrm{O}$, flux with 108 Carbowax 6000 solution, and rejection of Carbowax 6000. These samples will then be exposed to a solution containing $1.08 \times 10^{4} \mathrm{dis} /$ $\mathrm{min} / \mathrm{ml} \alpha$ activity for periods that will simulate six months, $1 \mathrm{yr}$, and $2 \mathrm{yr}$ of operating time. The membrane sample will then be recharacterized as to $\mathrm{H}_{2} \mathrm{O}$ flux, Carbowax 6000 flux, and rejection of carbowax. These results will then be compared to the results obtained before $\alpha$ irradiation. 


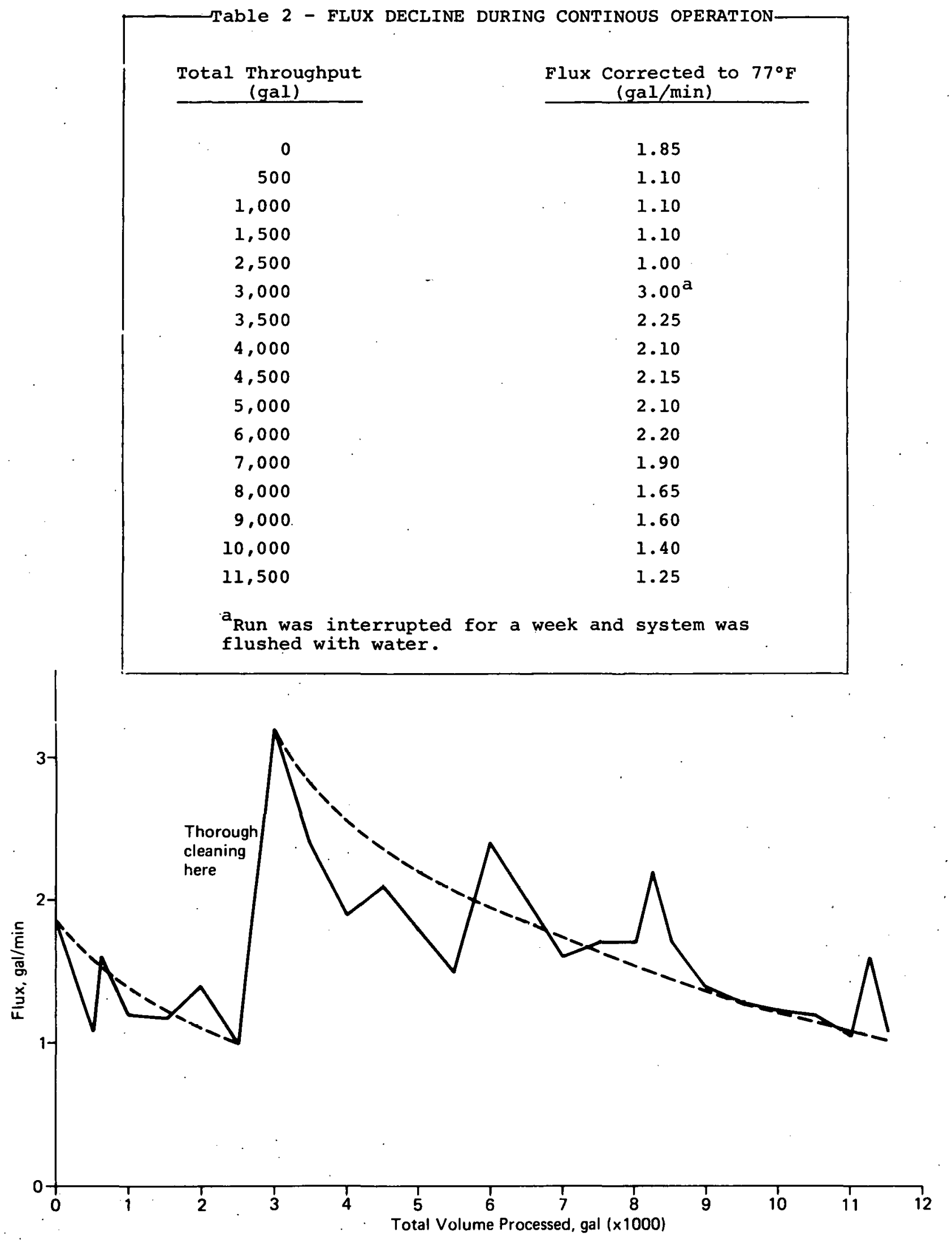

FIGURE 1 - Flux history during continuous processing. Peaks show flux recovery after cleaning or shutdown periods. Dotted line shows general trend of flux decline. 
The assessment of membrane mechanical properties following exposure to $B$ and $\gamma$ irradiation will be completed next quarter. The experiments employed to evaluate preand post-irradiation properties entailed dissolving each membrane in an appropriate solvent and measuring the resultant solution viscosities. These viscosity measurements were then used to compute the polymer molecular weights which were then compared to the original molecular weights.

A new type of membrane was obtained in tubular form. The membrane material is polysulfone and was manufactured on an experimental basis at our request. This membrane is currently designated as Type WRP and has a molecular weight cutoff of approximately 5000. Some difficulties occurred in casting the WRP membranes in 0.5 in. diameter tubes. As a result, membrane performance characteristics have not been uniform. Two tubes will be tested next quarter on contaminated solution from the Waste Processing Facility. One membrane has a low water flux $\left(2.6 \mathrm{gal} / \mathrm{ft}^{2} /\right.$ day) and moderate solids rejection (63.88), and the other has a high water flux (93.6 gal/ft ${ }^{2} /$ day) and low solids rejection (34.88). These data were taken at 75 psig inlet pressure, 50 psig outlet pressure, and 3-4 gal $/ \mathrm{min}$ circulation rate at $80^{\circ} \mathrm{F}$. The rejection data were measured with a 28 Carbowax 6000 solution. The variations in performance are attributable to the developmental nature of the casting procedure with this particular membrane formulation; that is, the viscosity of the WRP casting solution is approximately an order-of-magnitude lower than the viscosity of typical tubular membrane casting solution. These membranes should, however, provide sufficient data to assess the appli.icabiltiy of Type WRP membranes for processing of low-level nuclear waste water.

\section{Inorganic Adsorbents}

The small-laboratory-column $(0.7-\mathrm{cm}$ diameter) tests were completed. The results are tabulated in Table 3 . The feed solution to these columns is approximately $20,000 \mathrm{dis} / \mathrm{min} / \mathrm{ml}$ at a rate of $2 \mathrm{ml} / \mathrm{min}$ for all plutonium-238 and a feed solution of $40,000 \mathrm{dis} / \mathrm{min} / \mathrm{ml}$ at a rate of $20 \mathrm{ml} / \mathrm{min}$ for uranium-233. Breakthrough was achieved for the tests with uranium-233.

Isotherms were run on several inorganic adsorbents. A summary of the data is given in Table 4. Also, sodium titanate (NaTi ${ }_{2}{ }{ }_{5}$ ), as developed by Sandia Laboratories, is being tested and compared to previously evaluated inorganic adsorbents.

Tests on the Engineering Test Ion Exchange System were continued from last quarter. Waste solution from the waste Processing Facility was used as feed to the system. The waste solution was filtered through

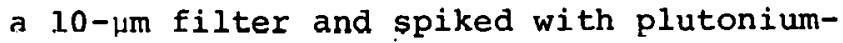
238. The bed volume of each column is $1000 \mathrm{ml}$ (50 mm diameter $\times 50.8 \mathrm{~cm}$ height). A sumary of the data is given in Table 5 . Decontamination factors as high as 98 were obtained using: feed concentrations of $20,000 \mathrm{dis} / \mathrm{min} / \mathrm{ml}$ gross alpha; with feed concentrations of $\sim 1000 \mathrm{dis} / \mathrm{min} / \mathrm{ml}$ gross alpha, decontamination factors (DF) dropped to w10.

Tests were started using ultrafiltration product from the ultrafiltration pilot plant to feed the Engineering Test Ion Exchange system. The feed was spiked with uranium-233 and fed to three different adsorbents. The results are given in Table 6. As can be seen, the MSA-1 resin yielded a maximum DF of 237 while the XN1010 and MSC-1 yielded DF's of $<10$. 


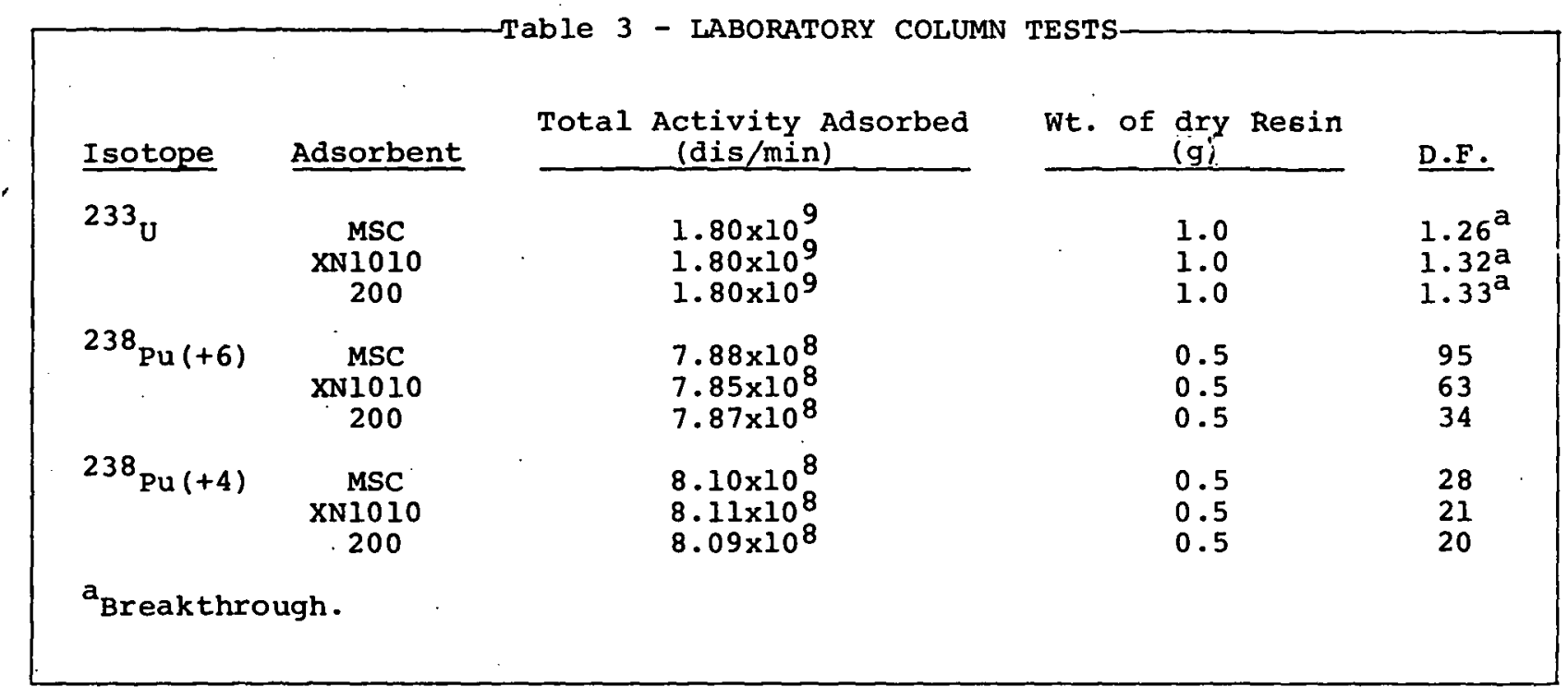

Table 4 - ADSORBENT ISOTHERM TESTS

\begin{tabular}{|c|c|c|c|c|c|}
\hline Adsorbent & Isotope & $\begin{array}{c}\text { Initial } \\
\text { Conc. } \\
\text { (dis/min/ml) } \\
\end{array}$ & $\begin{array}{c}\text { Adsorbent } \\
\text { Conc. } \\
(\mathrm{g} / \mathrm{ml}) \\
\end{array}$ & $\begin{array}{c}\text { Equilibrium } \\
\text { Adsorption } \\
\text { Coefficient } \\
\text { Kd } \\
\end{array}$ & $\mathrm{pH}$ \\
\hline $\begin{array}{l}\text { Titanium } \\
\text { Phosphate } \\
\mathrm{Ti}_{3}\left(\mathrm{PO}_{4}\right)_{4}\end{array}$ & ${ }^{233} \mathrm{U}$ & $\begin{array}{r}20,208 \\
20,208 \\
20,208 \\
16,213 \\
5,832\end{array}$ & $\begin{array}{c}7.89 \times 10^{-7} \\
3.94 \times 10^{-4} \\
7.889 \times 10^{-4} \\
3.94 \times 10^{-4} \\
3.9 \times 10^{2}\end{array}$ & $\begin{array}{l}2.18 \times 10^{7} \\
4.80 \times 10^{5} \\
6.9 \times 10^{5} \\
4.8 \times 10^{4} \\
1.6 \times 10^{2}\end{array}$ & $\begin{array}{l}2.4 \\
1.5 \\
2 \\
7 \\
10\end{array}$ \\
\hline $\begin{array}{l}\text { Zirconium } \\
\text { Phosphate } \\
\mathrm{Zr}_{3}\left(\mathrm{PO}_{4}\right)_{4}\end{array}$ & ${ }^{233} \mathrm{U}$ & $\begin{array}{l}19,619 \\
23,462 \\
18,648 \\
18,648\end{array}$ & $\begin{array}{l}4.42 \times 10^{3} \\
4.42 \times 10^{3} \\
8.86 \times 10^{2} \\
9.11 \times 10^{3}\end{array}$ & $\begin{array}{l}1.12 \times 10^{3} \\
7.37 \times 10^{2} \\
3.48 \times 10^{2} \\
1.69 \times 10^{4}\end{array}$ & $\begin{array}{l}3.2 \\
4.1 \\
7.5 \\
9.6\end{array}$ \\
\hline $\begin{array}{l}\text { Sodium } \\
\text { Titanate } \\
\text { NaHTi }_{2} 0_{5}\end{array}$ & ${ }^{233} \mathrm{v}$ & $\begin{array}{r}4,186 \\
19,759 \\
19,759 \\
23,672\end{array}$ & $\begin{array}{l}1.02 \times 10^{4} \\
1.0 \times 10^{4} \\
5.0 \times 10^{2} \\
2.5 \times 10^{2}\end{array}$ & $\begin{array}{l}4.16 \times 10^{4} \\
5.39 \times 10^{1} \\
4.49 \times 101 \\
2.56 \times 10^{3}\end{array}$ & $\begin{array}{l}9.8 \\
1.3 \\
3.4 \\
6.5\end{array}$ \\
\hline \multirow{2}{*}{$\begin{array}{l}\text { Sodium } \\
\text { Titanate } \\
\text { NaHTi }_{2}{ }^{0} 5\end{array}$} & ${ }^{238} \mathrm{Pu}(+6)$ & $\begin{array}{l}24,986 \\
15,701\end{array}$ & $\begin{array}{l}1.0 \times 10^{4} \\
1.0 \times 10^{4}\end{array}$ & $\begin{array}{l}1 \times 10^{2} \\
6.95 \times 10^{3}\end{array}$ & $\begin{array}{l}5.9 \\
9.2\end{array}$ \\
\hline & ${ }^{238} \mathrm{Pu}(+4)$ & $\begin{array}{l}10,446 \\
24,601\end{array}$ & $\begin{array}{l}1.01 \times 10^{4} \\
1.0 \times 10^{4}\end{array}$ & $\begin{array}{l}1.39 \times 10^{4} \\
2.5 \times 10^{3}\end{array}$ & $\begin{array}{l}9.8 \\
6.5\end{array}$ \\
\hline \multirow{2}{*}{$\begin{array}{l}\text { Ammonium } \\
\text { Molybdo- } \\
\text { phosphate }\end{array}$} & ${ }^{238} \mathrm{Pu}(+4)$ & $\begin{array}{l}17,630 \\
19,641\end{array}$ & $\begin{array}{l}9.7 \times 10^{6} \\
9.7 \times 10^{6}\end{array}$ & $\begin{array}{l}3.57 \times 10^{2} \\
1.82 \times 10^{2}\end{array}$ & $\begin{array}{l}4.3 \\
9.3\end{array}$ \\
\hline & ${ }^{238} \mathrm{Pu}(+6)$ & $\begin{array}{l}19,999 \\
19,035\end{array}$ & $\begin{array}{l}9.7 \times 10^{6} \\
9.7 \times 10^{6}\end{array}$ & $\begin{array}{l}2.57 \times 10^{3} \\
1.04 \times 10^{2}\end{array}$ & $\begin{array}{l}4.3 \\
7.0\end{array}$ \\
\hline \multirow{2}{*}{$\begin{array}{l}\text { Zirconium } \\
\text { Phosphate } \\
\mathrm{Zr}_{3}\left(\mathrm{PO}_{4}\right)_{4}\end{array}$} & ${ }^{238} \mathrm{Pu}(+4)$ & $\begin{array}{l}19,669 \\
20,350\end{array}$ & $\begin{array}{l}8.49 \times 10^{6} \\
8.84 \times 10^{6}\end{array}$ & $\begin{array}{l}7.25 \times 10^{3} \\
6.3 \times 10^{1}\end{array}$ & $\begin{array}{l}9.7 \\
4.9\end{array}$ \\
\hline & ${ }^{238} \mathrm{Pu}(+6)$ & $\begin{array}{l}22,920 \\
19,791\end{array}$ & $\begin{array}{l}4.4 \times 10^{2} \\
8.84 \times 10^{5}\end{array}$ & $\begin{array}{l}3.17 \times 101 \\
1.6 \times 10^{0}\end{array}$ & $\begin{array}{l}2.0 \\
3.0\end{array}$ \\
\hline \multirow[t]{2}{*}{$\begin{array}{l}\text { Titanium } \\
\text { Phosphate } \\
\mathrm{Ti}_{3}\left(\mathrm{PO}_{4}\right)_{4}\end{array}$} & ${ }^{238} \mathrm{Pu}(+4)$ & $\begin{array}{l}15,974 \\
11,731 \\
19,083 \\
19,573\end{array}$ & $\begin{array}{l}8.41 \times 10^{6} \\
7.89 \times 10^{5} \\
7.89 \times 10^{4} \\
7.89 \times 10^{5}\end{array}$ & $\begin{array}{l}1.67 \times 10^{4} \\
6.3 \\
1.02 \times 10^{2} \\
1.15 \times 10^{1}\end{array}$ & $\begin{array}{l}9.4 \\
4.5 \\
3.9 \\
3.0\end{array}$ \\
\hline & $238_{P}$ & $\begin{array}{l}18,700 \\
23,322\end{array}$ & $\begin{array}{l}7.89 \times 10^{5} \\
7.89 \times 10^{5}\end{array}$ & $\begin{array}{l}5.3 \times 10^{2} \\
8.3 \times 10^{0}\end{array}$ & $\begin{array}{l}4.4 \\
3.5\end{array}$ \\
\hline
\end{tabular}


Table 5 - RESULTS FROM THE ENGINEERING TEST ION

EXCHANGE SYSTEM WITH COMBINED WASTE-PLUTONIUM-238

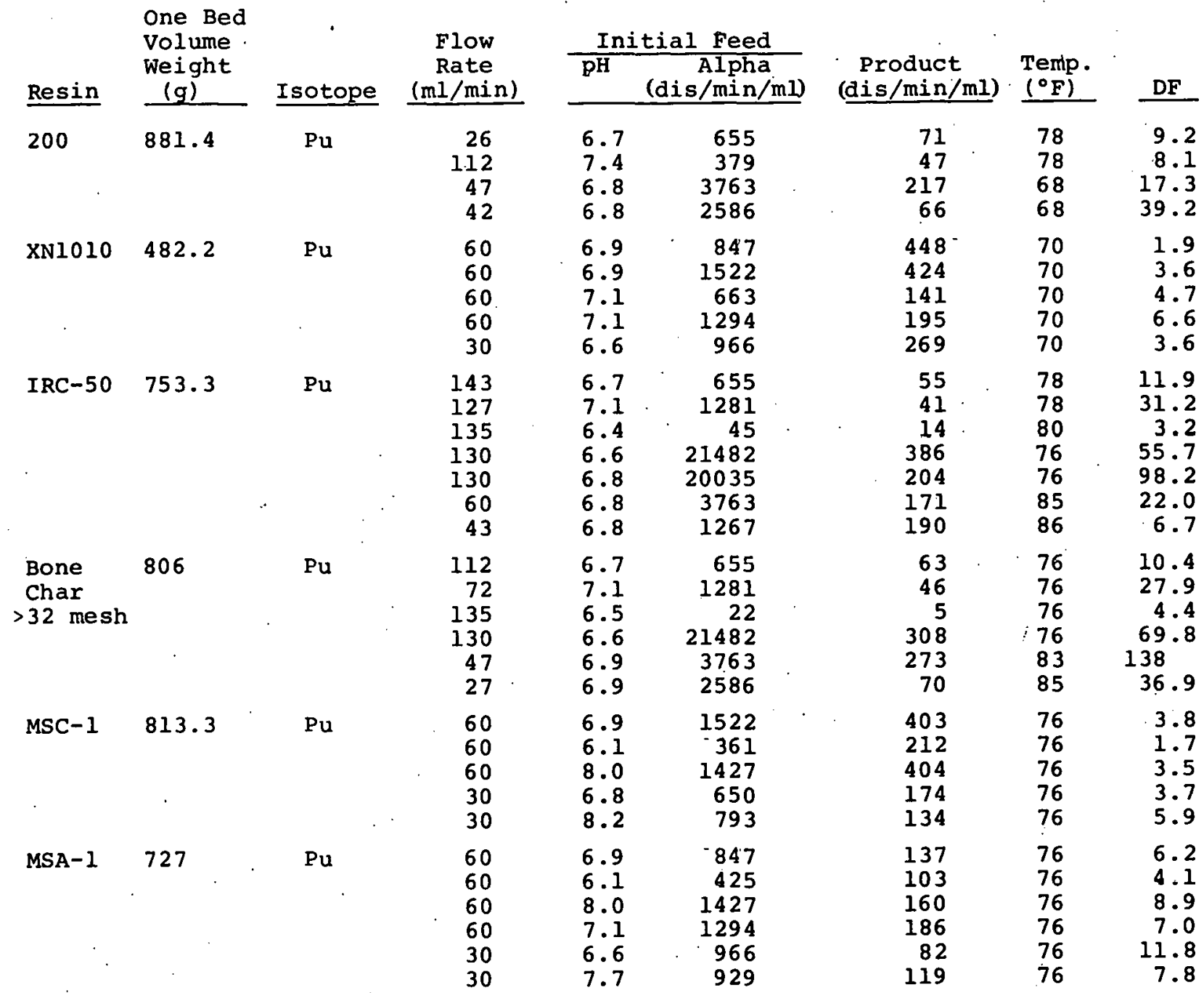




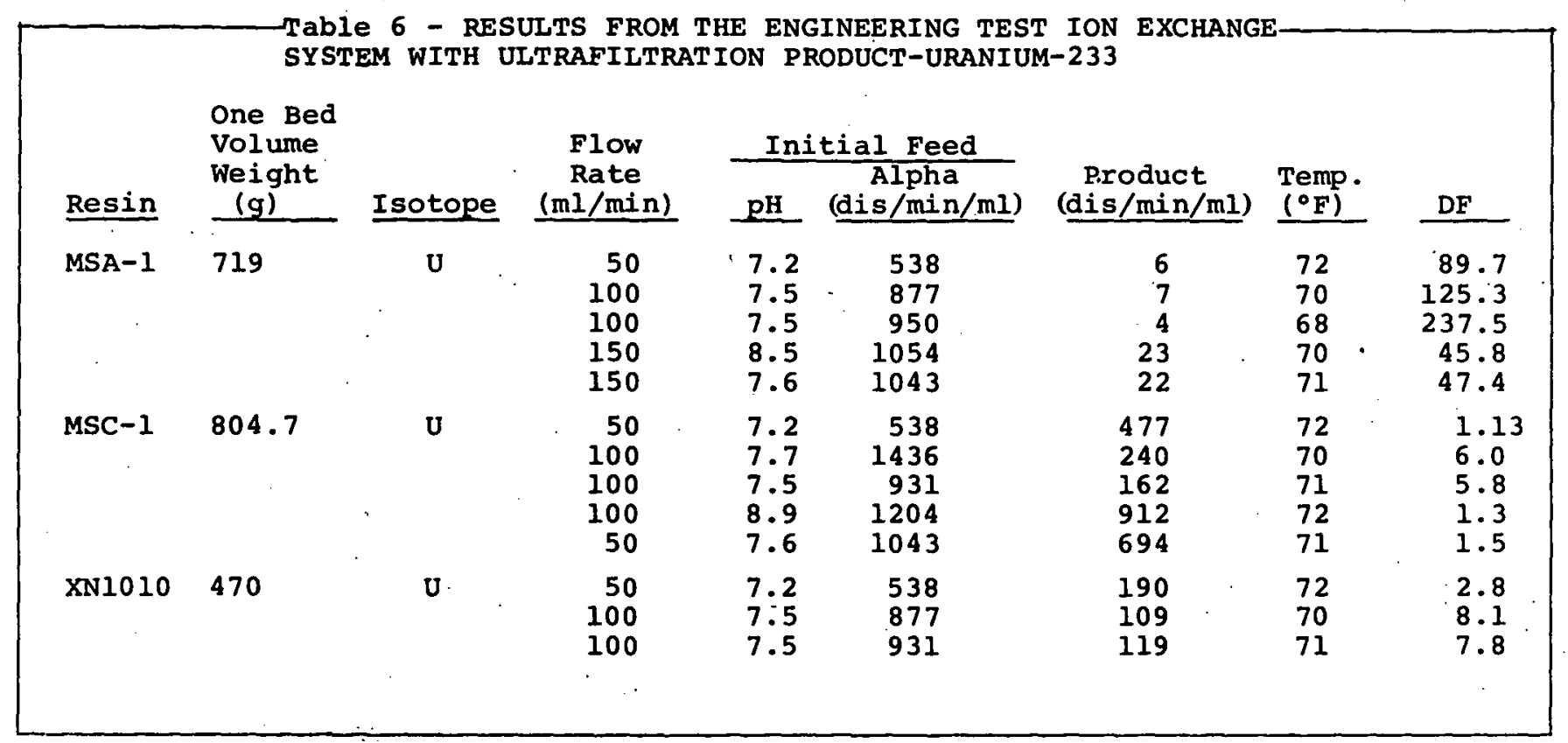




\section{Distribution}

EXTERNAL

TIC, UC-70 (267)

J. A. Chacon, DAO (2)

D. Davis, ALO (2)

D. W. King, ALO (2)

R. A. Wolfe, DURE

T. K. Keenan, LASL

J. O. Blomeke, ORNL

A. K. Williams, AGNS

J. A. Leary, WPR

R. E. Lerch, HEDL

R. K. Flitcraft, MRC

\section{INTERNAL}
A. G. Barnett
W. H. Bond
W. T. Cave
J. W. Doty
T. C. Elswick
K. V. Gilbert
C. W. Huntington
L. V. Jones
D. P. Kelly
J.W. Koenst (3)
B. R. Kokenge
D. F : Luthy
J. R. McClain
D. L. Prosser
I. B. Stevens
R. E. Vallee
H. L. Williams
Library (10)
Publications 